
Entrepreneurship and Management University od Social Sciences Publishing House ISSN 1733-2486 Volume XVI, Issue 2, pp. 31-44 DOI 10.1515/eam-2015-0015

\title{
Assessment of Financial Investors' Assets Level and Importance on Financial Market in Poland
}

\begin{abstract}
The main purpose of the submitted article is the estimation of financial investors' potential in Poland. There are four groups of collective investors on financial market in Poland like Banks, Insurance companies, Investment funds and Open Pension Funds, which have been analyzed. Their importance on financial market and especially on capital market in Poland is still rising. The dynamics of their assets value in $2009-2013$ periods has been analyzed. Financial investors' assets and Gross National Product in Poland ratio has been calculated. The influence of the financial crisis and post-crisis time on the investment portfolios structure has been also reviewed.
\end{abstract}

Key words: Collective investors, open pension funds, investment fund, financial instruments, investment portfolio.

JEL codes: G20, G23.

\section{Introduction}

Financial intermediaries are very important elements in the financial system of the state. They operate in the financial market as institutions that make possible for households and businesses to convert savings into investments. They create very strong demand on securities, which are issued on this market. The cores of the market are collective investors, like banks, insurance companies, investment funds and open pension funds.

The aim of this paper is to analyze the level of financial investors' assets and its evaluation in 2009 - 2013 periods. The paper formulates a research 
hypothesis, according to which in 2009 - 2013 period level of financial investors assets gradually increased as a result of the end of financial crisis time and high-risk forms of investment have been playing more important role in their investment portfolios.

\section{The essence of the business cycle}

A business cycle is a term which refers to the fluctuations in values measuring the amount of business activity occurring in a given country or region. They characterize the rate of changes in business around a long-term growth trend [Burda, Wypłosz 2000, p. 46].

The following economic indicators are most frequently used to evaluate the currently dominating trend:

- Gross Domestic Product,

- Level of employment,

- Price level,

- Exports value,

- Imports value,

- Investment expenditure,

- Personal income and expenditure,

- Income and profits of companies,

- Stock index value.

The following are the phases of a business cycle [Burda, Wypłosz 2000, p. 79]:

- expansion phase - production, employment, investment, demand and prices increase while unemployment decreases,

- peak phase - the end of growth, the aforementioned values stabilize at a high level,

- contraction phase - unemployment grows while production, employment, investment, demand and prices fall,

- trough phase - the end of contraction, the aforementioned factors remain at low level.

Depending on their length, business cycles may be divided into [Barczak 2006, p. 117]:

- Short (Kitchin cycles) - lasting 2-4 years, caused by inventory and wholesale price changes as well as settlement of bank operations,

- Medium (Juglar and Kuznets cycles) - lasting from 8 to 23 years, related to accumulation of production factors over a long period (investment, construction migration), 
- Long (Kondratiev wave) - lasting from 40 to 60 years, connected with discoveries and innovations and the process of their spreading over the world (electricity, steam engine, railway, computer, the Internet).

The financial crisis of 20072009 started with the collapse of the market of high-risk mortgage loans in the United States.

The crisis was triggered by banks giving subprime mortgage loans with high repayment risk to people with little financial capacity. Those loans became securities for bonds sold on a large scale by private financial institutions (including the biggest American and European banks) as investment or speculation. There was little awareness of how risky the bonds were, as it was the time when real estate market was growing, while at the same time the major rating agencies awarded high safety rates to those bonds. Individual insolvency of debtors resulted in the lack of cash on the credit market and instability of those institutions.

After two - year of financial crisis it's impact on financial markets is still present. A lot of financial institutions, enterprises and households still suffer from its negative effects.

\section{The role and importance of financial institutions in the financial system}

The financial system is a mechanism regulating financial relations between entities belonging to private, state and financial spheres, consisting of financial institutions, financial instruments, financial markets and rules defining the way they function [Wypych 2000, p. 104].

From the point of view of this analysis the segment of financial institutions is fundamental, in particular institutional investors who fulfill the valuable function of financial intermediaries. Using the financial instruments available them to transform savings to investment.

Institutional investors are public trust institutions. They possess the competence and the necessary knowledge in the field of investing funds on the financial markets. Households and companies entrust these specialized institutions with their surplus of funds (savings) to be invested in certain securities. Thanks to the professional management of funds investment risk is effectively lessened through diversification of the contents of investment portfolios, as well as through the choice of instruments with different level of risk and potential return [Owsiak 2002, p. 227].

The transformation process of savings into investments by using collective investors has been shown on figure 1 . 


\section{Figure 1. Mechanism of transformation of savings into investment}

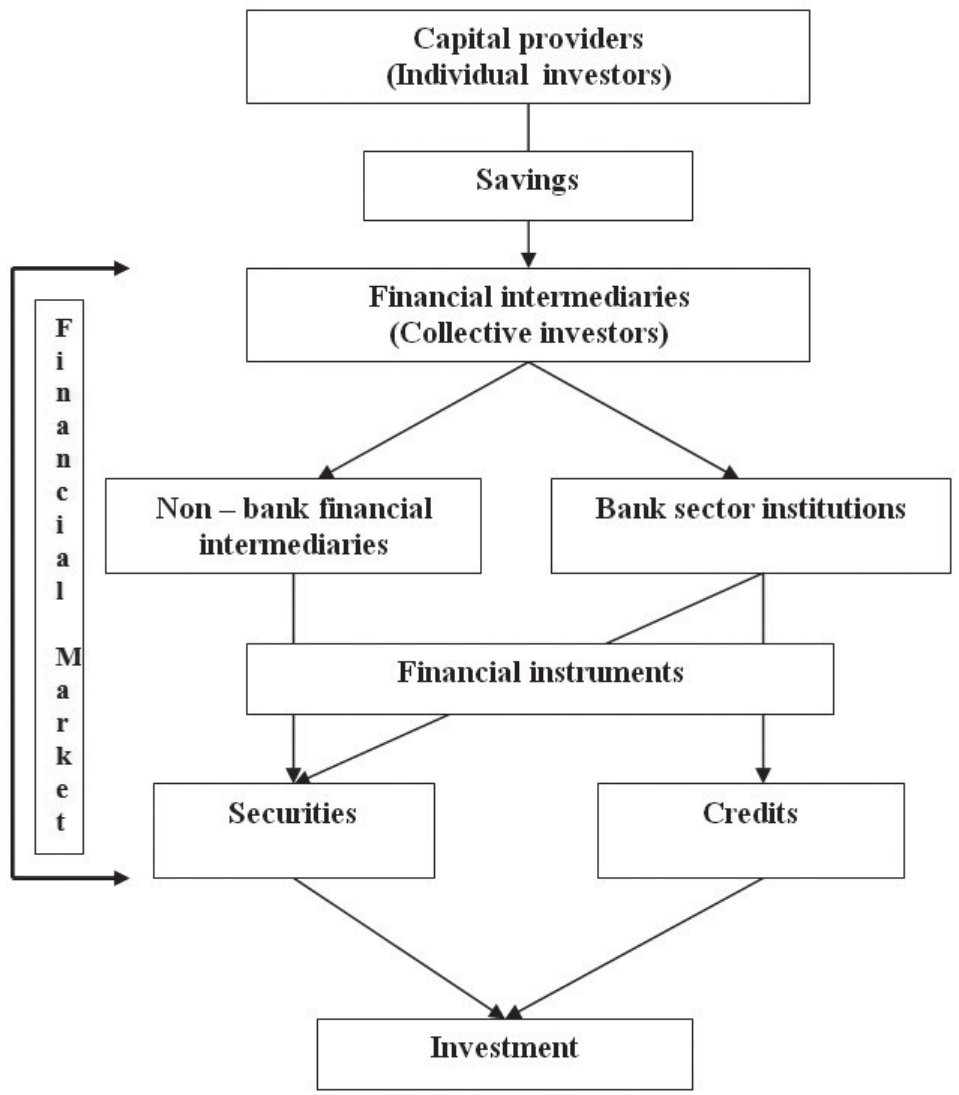

Source: own work based on Czekaj 2008, pp. 4-6.

The arguments which prove superiority of collective investment over individual one are the following [Proniewski, Niedźwiedzki 2001, p. 82]:

- professionalism - financial intermediaries employ highly qualified personnel and have better understanding of the financial market and the instruments it offers, which enables taking optimal investment decisions,

- $\quad$ investing flexibility - financial intermediaries have more opportunities to diversify the investment portfolio depending on the changing situation on the financial market, 
- concentration of savings - financial intermediaries having considerable financial resources at their disposal may take advantage of the scale and as they have more bargaining power they may purchase financial instruments on better conditions than individual investors,

- diversification of investment - having bigger financial resources they stand a better chance of adjusting the structure of their investment portfolio with reference to the relation of risk-return. Thanks to the diversification of investment portfolio, financial intermediaries may decrease the level of risk of its content.

Furthermore, other aspects of collective investment need to be emphasized. When investing their savings through financial institutions individual investors are freed from the necessity of constant monitoring of the financial market situation as well as gathering information about it in order to take the right investment decisions. Having bigger capital gives collective investors wider and more direct access to many financial instruments, which are not available for individual investors.

Major collective investors include:

- commercial banks (especially investment banks),

- insurance societies,

- pension funds,

- investment funds.

Commercial banks - the most common type of these banks are the credit-deposit banks which gain their capital from clients in the form of deposits and investment. They are the only institutions able to accept money from their clients on term deposits and transform them into credit funds. They also operate on the financial market using that part of the money procured from clients in the form of deposit or bonds which were not assigned for credit. The funds are engaged mostly in low-risk financial instruments such as treasury bills and bonds and less in high-risk securities like stock - exchange companies' shares [Szelągowska (red) 2009, pp. 28-29].

Banks whose main aim is to invest in securities are investment banks. These are institutions primarily dealing in the capital market and its instruments. We should differentiate between the operations of investment banks on the primary and secondary market. In the former they prepare and carry out the issue of securities as well as advise their issuers. In some cases banks take over the risk connected with success of the issue functioning as guarantors. On the secondary market investment banks activities may have two forms [Jacob, Klein 1998, pp. 17-19]: 
- investing in securities (as a dealer),

- carrying out client's orders to purchase or sell securities, sometimes also safe-keeping them.

Besides, their other functions include financial advisory services as well as mergers and acquisitions services.

Insurance companies - the aim of the insurance societies is to provide financial protection to insured people, which enables limiting negative effects of risk. These institutions gain capital in the form of insurance premium paid by clients. The insurance holders pay premium as a way of financial protection of themselves and other people insured in case action committed takes place [Marcinkowska 2007, pp. 42-44].

Insurance companies must be solvent. This involves their having own capital at the adequate level and conducting investment deals complying with the statutory requirements and limitations. The main aim of their investment activity is to achieve profitability with the maximum high level of safety and maintaining asset liquidity [Sułkowska 2001, p. 119].

The safety requirement makes it necessary for insurance companies to reduce the risk by diversification of the investment portfolio and high content of safe investment. Through investment the accumulated insurance capital returns to the financial system of the country and performs productive, prosupply role. The main categories of insurance companies' investment are:

- mortgage,

- real estate,

- $\quad$ securities (mostly safe - treasury bills and bonds),

- bank deposits.

Open pension funds - open pension funds are economic entities collecting contributions in order to turn a profit to those who pay them. As the consumption of the invested savings happens only after reaching pensionable age, the time scale of the investment of pension funds is relatively long. The general aim of the business of pension funds on the financial market requires minimal investment risk, therefore they must comply with various safety norms according to which the funds invest in financial instruments. This applies especially to open pension funds and funds connected with pension plans of employees, and to a lesser extent funds based on individual pension accounts - those three forms of savings accumulation are part of a social protection system and their activity is related to the social policy of the state (in the case of open pension funds accumulation of savings is enforced by the system) [Dybał 2008, p. 13]. Due to the change of legal acts starting from 2011 year the importance of open pension funds on financial markets has deteriorated. From May 1, the level of pension 
contribution decreased by 5 percentage points to 2,3\% ${ }^{1}$. February 1, 2014 treasury part of pension fund assets were transferred to the Social Insurance Institution, which meant to transfer the approximately $51,5 \%$ of the accounts of open pension fund members in the Social Insurance Institution accounts 2 .

Investment funds - investment funds most distinctly represent the idea of collective investing. In comparison to the other financial intermediaries investment on the financial market is their primary aim. Their clients are mainly individual persons, who for various reasons are not interested in investing their savings on their own. The services of these institutions are frequently used by other entities (banks, insurance companies, open pension funds), because the investment offer of investment funds is highly diversified while the management of the accumulated capital is professional. Moreover the fees charged by these funds are relatively low [Dawidowicz 2008, pp. 10-11].

As was mentioned before collective investors influence the national financial system and economic development. They form a crucial element of the demand side of the financial market. Accumulated capital is invested in financial instruments, contributing to the development of the monetary market, and particularly the capital market. Both of these markets are used by companies when financing current business activities or investment ventures. Demand for capital from companies depends on various factors such as macroeconomic, line of industry and internal issues. When making a decision to finance business through the financial market the company must take into account the fact that the capital obtained must be repaid and interest must be paid in return for using this capital. Such decision should, therefore, be preceded by a survey of the market and based on reliable economic calculus.

\section{The level of financial intermediaries' assets in Poland in 2009-2013}

The object of this analysis is the evaluation of influence of the situation on the financial market on the potential of institutional investors in Poland. This includes two areas:

- evaluation of assets possessed by collective investors as well as their structure,

- change of the level of assets engaged by investment funds and open pension funds in high-risk financial instruments.

\footnotetext{
${ }^{1}$ The Act of 25 March 2011 amending certain laws related to the functioning of the social security system, Journal of Laws of 2011 no 75, item 398.

2 The Act of 6 December 2013 amending certain acts due to the determination of rules of pension payments from the funds accumulated in open pension funds, Journal of Acts of 2013, item 1717.
} 


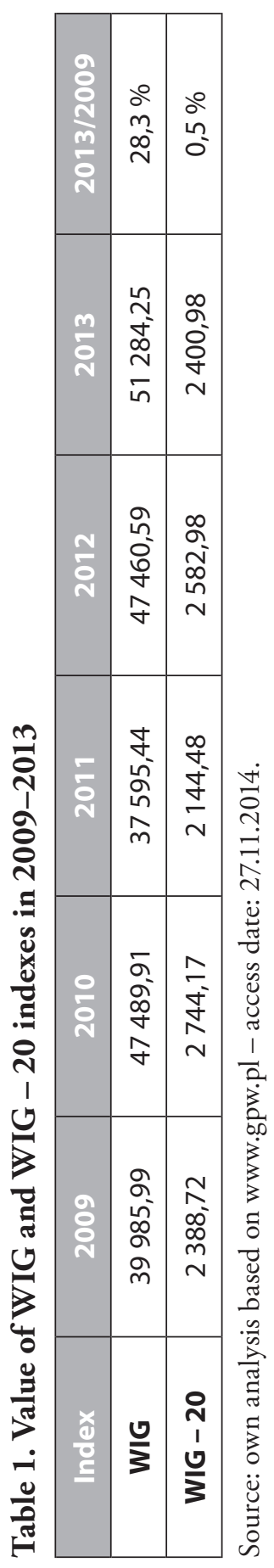


WIG means Warsaw Stock Exchange Index and WIG - 20 contains 20 biggest companies on capital market in Warsaw. During the analyzed period growth of both indexes was observed annually with the end of the growth period in 2010. In 2011 significant decrease of their value was registered, which was the effect of a considerable fall of the prices of shares on the Warsaw Stock Exchange. During the four analyzed years the index referring to all shares on the trading floor increased significantly by over $28 \%$, while the index based on the 20 largest companies has just increased its value by less than $1 \%$.

The conclusion can be drawn, that changes in pension system in Poland and riots in Ukraine at the end of 2013 year have influenced much more on bigger companies' shares prices on Warsaw Stock - Exchange.

The diagrams below and the table represent financial potential of collective investors in 2009-2013. The level of assets held by the segment of financial investors and its relation to Polish GDP is illustrated. In addition, the table presents the structure of this segment of the financial system.

Figure 2. Financial investors' assets in Poland in 2009-2013

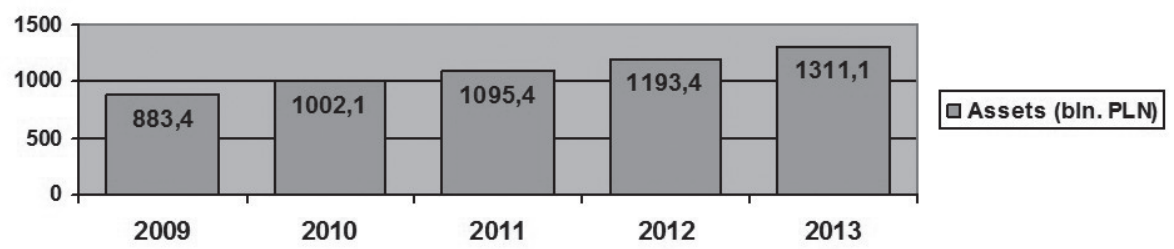

Source: own analysis based on www.knf.gov.pl - access date: 26.11.2014.

Table 2. Financial investors market distribution in $2009-2013$ period (share in \%).

\begin{tabular}{|l|c|c|c|c|c|}
\hline \multicolumn{1}{|c|}{ Institution } & 2009 & 2010 & 2011 & 2012 & 2013 \\
\hline Banks & 63,4 & 61,0 & 63,8 & 59,9 & 58,4 \\
\hline Open Pension Funds & 20,2 & 22,1 & 20,5 & 22,6 & 22,8 \\
\hline Investment Fund Companies & 10,6 & 11,5 & 10,5 & 12,2 & 14,4 \\
\hline Insurance Society & 5,8 & 5,4 & 5,2 & 5,3 & 4,4 \\
\hline
\end{tabular}

Source: own analysis based on www.knf.gov.pl - access date: 25.11.2014. 


\section{Figure 3. The share of financial investors' assets to GDP in Poland} in 2009-2013

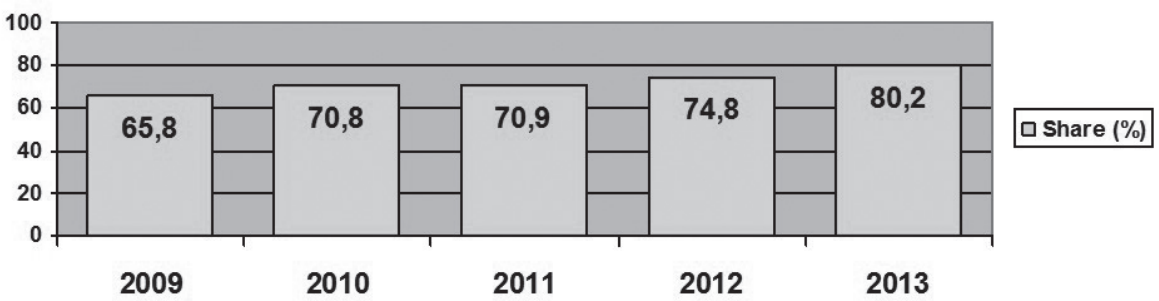

Source: own analysis based on www.knf.gov.pl and www.stat.gov.pl - access date: 28.11.2014.

It is important to note that despite the fluctuations on financial markets, changes in social security system and uncertainty on Ukraine the level of financial investors' assets in Poland has been annually growing. The level of growth in four-year period was more than $48 \%$, which must be considered as a positive result. In 2010 year total assets of financial intermediaries in Poland for the first time have reached 1 billion PLN limit. Quite favorable situation on Warsaw Stock - Exchange has affected the growth of importance of investment funds and pension funds at the expense of reducing the level of bank deposits.

In 2012 share of banks in financial investors market for the first time has fallen under $60 \%$ limit. In analyzed period share of banks has been reduced by 5 percentage points.

In 2009-2013 period the importance of investment funds has increased. Their market share has increased by 3,8 percentage points.

The growth of open pension funds market share was due to constant flow of cash to portfolios from the contributions paid by the future pensioners. It can be assumed that 2013 year was the last one with such a high share of open pension funds in financial investors' market. The changes in law which have been described in previous part of this article shall negatively influence the importance of open pension funds as financial investors starting from 2014 year.

Very important conclusion is that the rate of financial investors' assets growth has been faster than the rate of GDP growth. As a result the ratio between financial investor's assets level and value of GDP in Poland has increased in four-year period by 14,4 percentage points, for the first time reaching $80 \%$ limit.

The last part of the present survey analyzes the level of engaging in the high-risk instruments by Open Pension Fund and investment funds. In the 
case of Open Pension Fund the components of their portfolios include (until 2013 year):

- Shares,

- Treasury debtor securities and bank deposits,

- Others.

In the case of investment funds they were divided as follows:

- Aggressive,

- Mixed,

- Safe (treasury bonds, money market),

- Private equity,

- Others.

Table 3. Structure of investment portfolios of Open Pension Funds in 2009-2003

\begin{tabular}{|c|c|c|c|c|c|c|}
\hline \multirow{2}{*}{ Instrument } & \multicolumn{5}{|c|}{ Share (\%) } & \multirow{2}{*}{$\begin{array}{c}2013 / 2009 \\
\text { (p.p.) }\end{array}$} \\
\hline & 2009 & 2010 & 2011 & 2012 & 2013 & \\
\hline Shares & 30,7 & 36,6 & 31,2 & 35,2 & 41,8 & $+11,1$ \\
\hline Safe & 61,9 & 58,3 & 56,9 & 54,2 & 50,4 & $(11,5)$ \\
\hline Others & 7,4 & 5,1 & 11,9 & 10,6 & 7,8 & $+0,4$ \\
\hline
\end{tabular}

Source: own analysis based on www.knf.gov.pl - access date: 27.11.2014.

The table above confirms positive trend in term of the level of engaging of pension funds in shares. During analyzed period the share of stock - exchange companies high - risk securities has increased by more than 11 percentage points. It's a clear signal that their portfolios managers have been convinced that this market has strong increasing potential.

Low level of inflation in Poland has directly influenced the interest of treasury debt securities. The low level of return from these securities has affected the more than 10 percentage points fall of their shares in open pension funds portfolios.

As mentioned in previous part of this paper 2013 is the last year of this kind of open pension funds investment portfolios structure. Treasury debt securities have been on 1 February 2014 transferred to Social Insurance Institution. From this date open pension funds investment portfolios are very similar to mixed and aggressive portfolios of investment funds. 
Table 4. Structure of the investment funds market in Poland in 20092013 period

\begin{tabular}{|l|c|c|c|c|c|c|}
\hline \multirow{2}{*}{ Instrument } & \multicolumn{5}{|c|}{ Share (\%) } & \multirow{2}{2}{$013 / 2009$} \\
\cline { 2 - 6 } & $\mathbf{2 0 0 9}$ & $\mathbf{2 0 1 0}$ & $\mathbf{2 0 1 1}$ & $\mathbf{2 0 1 2}$ & $\mathbf{2 0 1 3}$ & $($. p. \\
\hline Aggressive & 29,1 & 27,2 & 19,3 & 16,8 & 16,0 & $(13,1)$ \\
\hline Mixed & 40,5 & 25,3 & 18,9 & 13,8 & 11,3 & $(29,2)$ \\
\hline Safe & 22,9 & 26,7 & 31,3 & 37,7 & 34,2 & $+11,3$ \\
\hline Private equity & 2,3 & 12,4 & 18,8 & 16,0 & 19,7 & $+17,4$ \\
\hline Others & 5,2 & 8,4 & 11,7 & 15,7 & 18,8 & $+13,6$ \\
\hline
\end{tabular}

Source: own analysis based on www.izfa.pl - access date: 04.12.2014.

Data presented in table above clearly shows trend on investment funds market. High -risk funds annually are less popular among investors which gave the effect of more than 42 percentage points decrease of aggressive and mixed funds' share in the market. Investors gradually transferred their savings to lowrisk funds which gained $34 \%$ share in the market (11,3 percentage growth in four-year time).

Noteworthy is the increased of share of private equity funds. These funds have shares of not listed on Warsaw Stock - Exchange companies. They are quite a new investment product in polish financial market but as can be noticed in table above are becoming more and more popular among investors in Poland.

\section{Conclusions}

The hypothesis, formulated in this paper has been partially revised positively. The level of financial investors' assets in Poland in after - crisis period has gradually increased during 2009-2013 years. Their financial potential is annually growing, that is reflected in increasing ratio between their assets and value of GDP in Poland. This ratio level has reached at the end of 2013 year $80 \%$ limit for the first time in history.

The importance of open pension funds and investment funds has gained during analyzed period at the expense of the importance of banks deposits and assets of insurance companies.

The second part of hypothesis cannot be clearly revised positively. Indeed the share of high-risk instruments in open pension funds portfolios has increased and the same situation can be observed in term of private equity in- 
vestment funds but in the same period very significant loss of aggressive and mixed investment funds' share in the market has been recorded.

The final conclusion is that 2014 year will bring changes on financial intermediaries' market situation. The reasons are changes in law in social security system, improving condition of polish economy, households and enterprises. The importance of open pension funds will not be any longer so significant, the more important role on the market should play banks and investment funds, especially those with high-risk investment portfolios, such as a private equity funds.

\section{References}

\section{Literature}

Barczak R. (2006), Nowe oblicza cyklu koniunkturalnego [The new faces of The business cycle], PWE, Warszawa.

Burda M., Wypłosz C. (2000), Makroekonomia - podręcznik europejski [Macroeconomics - european handbook], PWN, Warszawa.

Czekaj J. (2008), Rynki, instrumenty i instytucje finansowe [Market, instruments and financial institutions], PWN, Warszawa.

Dawidowicz D. (2008), Fundusze inwestycyjne [Investment funds], CeDeWu, Warszawa.

Dybał M. (2008), Efektywność inwestycyjna funduszy emerytalnych [Pension funds' Investment efficiency], CeDeWu, Warszawa.

Jacob A., Klein J. (1998), Investment banking, Poltext, Warszawa.

Marcinkowska M. (2007), Ocena dziatalności instytucji finansowych [Appraisal of operations of financial institutions], Difin, Warszawa.

Owsiak S. (2002), Podstawy nauki finansów [Learning basics of finance], PWE, Warszawa.

Proniewski M., Niedźwiedzki A.M. (2001), Rynek pieniężny i kapitatowy. Podstawy teorii i praktyki [Monetary and capital market. Theory and practice basics], Wyższa Szkoła Finansów i Zarządzania w Białymstoku, Białystok.

Sułkowska W. (2001), Ubezpieczenia, zagadnienia podstawowe [Insurance, basic issues], WSZiB, Kraków.

Szelągowska A. (Eds.) (2009), Wspótczesna bankowość inwestycyjna [Contemporary Investment Banking], CeDeWu, Warszawa.

Wypych M. (2000), Finanse i instrumenty finansowe [Finance and financial instruments], Absolwent, Łódź. 


\section{Legal acts:}

The Act of 25 March 2011 amending certain laws related to the functioning of the social security system, Journal of Laws of 2011 no 75, item 398.

The Act of 6 December 2013 amending certain acts due to the determination of rules of pension payments from the funds accumulated in open pension funds, Journal of Acts of 2013, item 1717.

\section{Electronic bibliography:}

www.gpw.pl.

www.izfa.pl.

www.knf.gov.pl.

www.stat.gov.pl. 